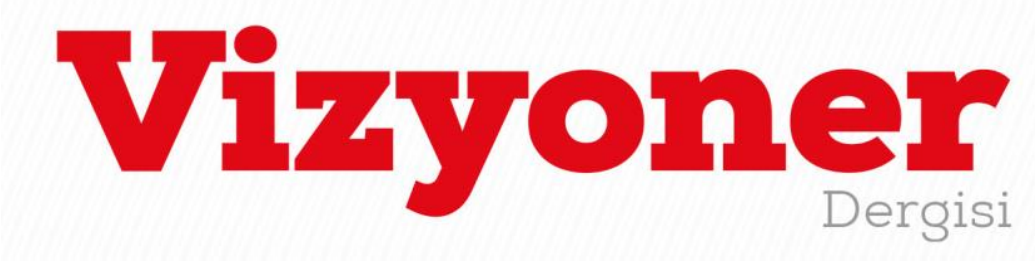

Süleyman Demirel Üniversitesi Vizyoner Dergisi, Yıl: 2022, Cilt: 13, Sayı: 33, 236-253.

Süleyman Demirel University Visionary Journal, Year: 2022, Volume: 13, No: 33, 236-253.

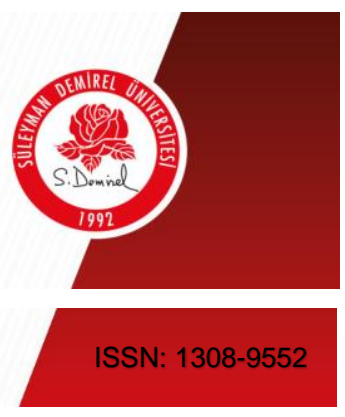

ARAŞTIRMA MAKALESİ / RESEARCH ARTICLE

\title{
THE WEALTH OF OTTOMAN INDIVIDUALS BY DIFFERENT SOCIO-ECONOMIC GROUPS, 1650-1918: A DESCRIPTIVE ANALYSIS IN THE CONTEXT OF INSTITUTIONAL CHANGE
}

\author{
FARKLI SOSYO-EKONOMIKK GRUPLARA GÖRE OSMANLI BİREYLERİNIN \\ ZENGINLİĞİ, 1650-1918: KURUMSAL DEĞİşiM BAĞLAMINDA BETIMSEL BİR \\ ANALIZ
}

\author{
Res. Asst. Dr. Bora ALTAY ${ }^{1}$ \\ Asst. Prof. Dr. Koray GÖKSAL ${ }^{2}$ \\ Hande Nur KIRMIZIKUŞAK ${ }^{3}$
}

\begin{abstract}
The study offers a descriptive analysis of individual wealth in the Ottoman Empire, employing a new dataset from inheritance records of 36 different provinces located in Anatolia. The main purpose is to contribute to the discussion on the relationship between wealth inequality and changing institutional structures, spanning from 1650 to 1918 . The limitations of data entail restrictions to construct a quantitative research, and hence, the study provides an implicit analysis on this relationship. A new dataset on individual wealth, however, allow to present a descriptive analysis in a long-term perspective. Establishing information on individual wealth by socio-economic groups, the study estimates wealth inequality according to Gini coefficients. This estimates also include a comparative analysis among different groups, including four quartiles starting from the wealthiest 25 percent. Our findings underlie the importance of the role of institutional change over the wealth inequality. We suggest the wealth inequality is higher under the periods of decentralized institutions, particularly during the pre-industrial period. This trend has become better with series of political, economic and institutional reforms towards centralization during the second half of the nineteenth century.
\end{abstract}

Keywords: The Ottoman Empire, Institutional Change, Wealth, Wealth Distribution, Long-Term Perspective.

JEL Classification Codes: B15, B52, N25, N35.

ÖZ

İmparatorluğu'ndaki bireysel servetlerin betimleyici bir analizini sunmaktadır. Temel amaç, 1650'den 1918'e kadar uzanan, servet eşitsizliği ve değişen kurumsal yapılar arasındaki ilişkiye ilişkin tartışmaya katkıda bulunmaktır. Verilerin sınırlılıkları, nicel bir araştırma yapmak için kısıtlamalar getirmektedir ve bu nedenle, bu çalışma bu ilişki hakkında örtük bir analiz sunmaktadır. Bununla birlikte, bireysel servet üzerine yeni bir veri seti, uzun vadeli bir perspektifte tanımlayıcı bir analiz sunmaya izin vermektedir. Sosyoekonomik gruplara göre bireysel servet hakkında bilgi veren bu çalışma, servet eşitsizliğini Gini katsayılarına göre tahmin etmektedir. Bu tahminler, en zengin yüzde 25 'ten başlayarak diğer çeyreklik dilimler dahil olmak üzere farklı gruplar arasında karşılaştırmalı bir analiz de sunmaktadır. Bulgularımız, kurumsal değişimin servet eşitsizliği üzerindeki rolünün öneminin altını çizmektedir. Servet dağılımı özellikle ademi merkeziyetçi kurumların hakim olduğu dönemde daha eşitsizdir. Ancak bu eğilim 19. yüzyılda merkezi yapının güçlendirilmesi için yapılan iktisadi, politik ve kurumsal dönüşümlerle daha adil bir dağılıma yönelmiştir.

Anahtar Kelimeler: Osmanlı İmparatorluğu, Kurumsal Değişim, Servet, Servet Dağılımı, Uzun Dönemli Yaklaşım.

JEL Sinıflandırma Kodları: B15, B52, N25, N35.

(D) Ankara Yıldırım Beyazıt University, Faculty of Political Sciences, Department of Economics, baltay@ybu.edu.tr
(D) Ankara Yıldırım Beyazıt University, Faculty of Political Sciences, Department of Economics, kgoksal@ybu.edu.tr
(D) Ankara Yıldırım Beyazıt University, Social Science Institute, Department of Economics, handekirmizikusak@gmail.com

Makale Geliş Tarihi / Received : :29.06.2021

Makale Kabul Tarihi / Accepted $\quad: 12.12 .2021$ 


\section{GENIŞLETILMIŞ ÖZET}

\section{Amaç ve Kapsam:}

Son birkaç yılda Osmanlı İmparatorluğu'nda bireysel servetler ve servet dağılımı üzerine artan önemli bir literatür ortaya çıkmaya başlamıştır. Bu literatür içerisindeki ilk çalışmalar genel olarak tek bir kente ve sınırlı bir döneme odaklanmaktadır. Bununla birlikte, arşiv kayıtları üzerine yapılan daha derin çalışmalar bu analizlerin kapsamını genişletmiştir. Bu çalışmanın amacı, 1650 ile 1918 yıllarını kapsayan dönem için Osmanlı İmparatorluğu'nun Anadolu bölgesinde bulunan şehirlerin mahkeme kayıtları üzerinden bir servet analizi gerçekleştirmektir. Mahkeme kayıtları vefat eden bireylerin servetleri ile ilgili ayrıntılı bilgiler içermektedir. Kişinin unvanı, nakit varlıkları, gayrimenkulleri, değerli envanterleri, borç miktarları ve mahkeme masrafları mahkemelerce tutulan miras kayıtlarında ayrıntılı şekilde sunulmaktadır. Bu çalışma, kapsamı sınırlı tutmak adına servet analizlerinde vefat eden kișilerin unvanları ve toplam servetleri üzerinden bir analiz gerçekleştirmektedir. Tarihsel verilerin yaratmış olduğu sınırlılıklardan ötürü, bu çalışmada kullanılan servet değerleri mutlak değerleri yansıtmamaktadır. Bunun yerine, elde edilen servet değerleri üzerinden dönemsel bir karşılaştırma sunulmuştur. Servetler ve dağılımlarında ortaya çıkan dönemsel farklılıklar ise kurumsal yaklaşım üzerinden soyut bir analize tabi tutulmuştur. Bu soyut analiz için kişi başı gelir ve vergi tahminleri nicel kanıtlar olarak kullanılmıştır. Özellikle kurumsal değişimlerin iktisadi performans üzerindeki etkilerinin servetlerin seyri ve dağılımı üzerinden incelenmesi bu çalışmanın kapsamını şekillendirmektedir.

\section{Yöntem:}

$\mathrm{Bu}$ çalışma tarihsel veriler nedeniyle ortaya çıkan problemleri en aza indirmek için servet analizlerinde yaygın olarak kullanılan yöntemlere başvurmaktadır. Yöntem iki farklı iktisadi değişkene dayanmaktadır. Bunlardan birincisi Gini katsayılarıdır. Çalışma ilk olarak servet dağılımının uzun dönemli analizi için 50 yıllık alt periyotlar oluşturmuştur. Her bir periyot için Gini katsayıları hesaplanmış ve bu katsayılardaki değişimler üzerinden kurumsal değişimin servet dağılımı üzerindeki etkisi analiz edilmiştir. İkinci olarak, bu çalışma yine tarihsel veri setlerinde ortaya çıkabilecek sınırlılıkları en aza indirmek için ortalama servet değerlerine başvurmuştur. Miras kayıtlarında tespit edilen servet değerlerinin gerçek servet miktarlarını yansıttığını iddia etmek zordur. Özellikle Osmanlı mahkemelerinde çalışan memurların varlıkları değerlemesi ile elde edilen değerler önemli bir tartışma konusudur. Değerleme işlemlerinin bir kısmı piyasa fiyatlarını yansıtırken bir kısmı ise farklı sebeplerden dolayı yansıtamamaktadır. Bu nedenle, bu çalışma mutlak servet miktarlarını tahmin etmek yerine belirli servet grupları oluşturmuş ve bu gruplar arası değişkenliği incelemiştir. En zengin yüzde 25'lik dilimden başlayarak dört farklı refah grubu oluşturulmuştur. Analizler bu grupların ortalama servet değerlerini oluşturulan örneklem üzerinden incelemiştir. Aynı yöntem üzerinden iki farklı grup oluşturulmuştur. Bu gruplar unvanlı ve unvansız bireylerden oluşturulmuştur. Bu gruplar arasında da karşılaştırmalı bir analiz yüzde 25'lik dilimler ve Gini katsayıları üzerinden gerçekleştirilmiştir.

\section{Bulgular:}

Bu çalışmanın bulguları iki farklı kalem halinde sunulmuştur. En zengin yüzde 25'in ortalama servet değerleri dışarıda tutulduğunda, sunulan örneklemin büyük çoğunluğunu oluşturan diğer grupların ortalama servetleri Osmanlı ekonomisinin uzun dönemli seyri hakkında bulgular sunmaktadır. İlk bakışta, alt periyotlara göre ortalama servet değerleri U şeklinde bir eğilim göstermektedir. Bu bulguya göre, Osmanlı ekonomisi on yedinci yüzyılın son dönemlerinde ve on sekizinci yüzyılın başlarında büyürken, özellikle on sekizinci yüzyılın büyük bölümünde ve on dokuzuncu yüzyılın ortalarına kadar durağan bir dönem geçirmiştir. Ortalama servet gelirlerinin analizlerinden elde edilen bu bulgular, kişi başı gelir ve vergiler incelendiğinde elde edilen sonuçların tutarlı olduğuna işaret etmektedir. On dokuzuncu yüzyılın ortalarına doğru uygulanan politik reformalar ve iktisadi dönüşümler merkezi yapıyı güçlendirmiş ve bu dönemden itibaren iktisadi büyüme gerçekleştirmiştir. İkinci olarak, Gini katsayılarının seyri ele alınan alt dönemlerdeki ekonomik performans ile uyumludur. Bir başka deyişle, Gini katsayılarının yükseldiği dönemler, Osmanlı ekonomisinin durağanlık dönemleri ile örtüşmektedir. Diğer taraftan, iktisadi büyümenin gerçekleştiği dönemlerde ise Gini katsayıları önemli ölçüde azalmıştır. Özellikle durağanlık dönemleri, politik ve iktisadi kurumları oluşturan iltizam ve malikane sözleşmelerinin etkinliğini kaybettiği dönemlere denk gelmektedir.

\section{Sonuç ve Tartışma:}

Bu çalışma Osmanlı İmparatorluğu'nda bireylerin servetlerini tahmin etmekten ziyade servetlerin belirlenen alt dönemlere göre seyrine ve dağılımına odaklanmaktadır. Elde edilen bulguların seyri ile kurumsal dönüşüm süreci beraber analiz edildiğinde iki farklı sonuca ulaşıııı̧ı̧ır. Bunlardan birincisi kurumların iktisadi performanslardaki rolüne odaklanan literatüre katkıda bulunmaktadır. Kurumsal çevre ademi merkeziyetçi yapılara doğru kaydıkça etkinlik azalmakta ve iktisadi büyüme sınırlı olmaktadır. Bununla birlikte, kurumsal çevrenin merkezi yapılara doğru kayması ve etkin mekanizmaların uygulanmaya başlaması iktisadi büyümeyi hızlandırmaktadır. Çalışmada sunulan ortalama servet değerlerinin ve Gini katsayılarının seyri bu argümanı desteklemektedir. İkinci olarak, gruplar için karşılaştırmalı yapılan analiz sonuçlarına göre unvansız bireyler arasındaki servet dağılımı unvanlı bireylere göre daha etkindir. Bunun sebebi, unvansız bireylerin miras kayıtlarının oluşturulmasında yanlılığın düşük olması görülmüştür. Bu çalışma, son yıllarda hızla artmakta olan Osmanlı İmparatorluğu'nda servet literatürüne yeni bir katkı sunmaktadır. Bu katkı büyük oranda yeni veri seti üzerinden yapılan analizlere dayanmaktadır. Aynı zamanda, daha uzun dönemli ve farklı bölgeleri kapsayan veri seti üzerinden yapılan bu çalışmanın sonuçları ver sınırlılıklarına rağmen daha kapsayıcı bulgular sunmaktadır. Bu anlamda, bu çalışma Osmanlı İmparatorluğu'nu kapsayan bireysel servetler üzerine inşa edilen literatürde süregelen tartışmalara tarihsel kanıtlar üzerinden nicel ve nitel yeni tartışma alanları açmıştır. Bu çalışmanın bulgularının ileri ki çalışmalar için önemli bir kaynak olması beklenmektedir. 
Süleyman Demirel Üniversitesi Vizyoner Dergisi, Yıl: 2022, Cilt: 13, Sayı: 33, 236-253.

Süleyman Demirel University Visionary Journal, Year: 2022, Volume: 13, No: 33, 236-253.

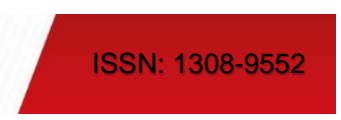

\section{INTRODUCTION}

In the last few decades, there has been growing literature over the role of institutions on the economic performances of societies, particularly for the pre-industrial period (Kennedy, 1988; North, 1990; Tilly, 1990; Greif, 2006; Van Zanden, 2009; North et al., 2009; Acemoğlu \& Robinson, 2012; Hoffman, 2015; Rubin, 2017). The wealth (capital) accumulation has also become one of the most important debates in economic history literature (Jones, 1970; Anderson, 1975; Shammas, 1978; Van Zanden, 1995; Hoffman et al., 2002; Chor, 2005; Bengtsson et al., 2018). The main argument of this literature has been that each society developed diverse institutional mechanisms to establish welfare-enhancing mechanisms during the early modern period. In the last few years, this literature has attracted the attention of Ottoman economic historians. Few studies, in particular, are pertinent to economic performances regarding wealth inequality, social welfare, and living standards (Özmucur \& Pamuk, 2002; Cosgel \& Ergene, 2011, 2012; Ergene et al., 2013; Kotzageorgis \& Papastamatiou, 2014; Altay \& Bulut, 2017; Canbakal $\&$ Filiztekin, 2021). A substantial body of this literature has focused on wealth analyses of a single province and a limited time. Hülya Canbakal and Alpay Filiztekin (2021) have presented one of the most comprehensive wealth analyses that contain different regions and a long-term perspective.

This study offers an analysis of wealth inequality by focusing on 36 different cities of Ottoman Anatolia, spanning from 1650 to 1918. The literature on Ottoman institutions has argued that the Ottoman Empire faced series of economic, political and institutional transformations during this period (Çizakça, 1996; Darling, 1996; Pamuk, 2004a, 2009; Karaman \& Pamuk, 2010; Tezcan, 2010, Yaycığlu, 2016; Rubin, 2017). While Ottoman economic historians have examined the economic performance through institutional change, the major findings have been based on implicit analysis instead of explicit and quantitative approaches. A limited number of studies, however, have presented explicit and quantitative analysis even if they mostly are in an urban context for a limited period, as mentioned above. This study has attempted to fill this gap by generating new data series, covering different provinces and longer periods for the Ottoman Empire.

In this sense, this study has a dual aim in contributing the recent literature of wealth inequality in the Ottoman Empire. First is to incorporate inheritance records from different regions of the Ottoman Empire. Employing higher numbers of inheritance records from different regions, this study has targeted to obtain average wealth levels as little deviation as possible. Including large-scale towns may cause the average wealth levels to be higher they should be. Thus, the new dataset that included in this study has contained not only large-scale towns of Anatolia but also rural towns and cities. Furthermore, this study has offered a comparative analysis on individual wealth levels by titles. Although it is difficult to determine whether the titles of individuals were honorific, this study has focused on whether individuals had a title (Öztürk, 1995, p. 44). In other words, the scope of this study has excluded a classification over titles of individuals. The key is to present the long-term trend of average wealth levels titled and untitled individuals in a comparative perspective. The main problem aimed at examining is that, did average wealth levels of these different groups converge with the inclusion of centralized structures over time? The second aim is to show the relationship between wealth inequality, aggregate average wealth levels and institutional change through Gini coefficients in the Ottoman Empire. The key hypothesis is that institutional change towards centralized structures caused better wealth distribution, particularly from the second half of the nineteenth century. The main contribution of this study, in this perspective, is to conduct an examination over such questions that are overlooked by the recent literature.

Ottoman inheritance records are one of the oldest inventory traditions from the beginning of the early modern period. The earliest records date from the first half of the sixteenth century, and the series continues until the demise of the Ottoman Empire (Barkan, 1966; Canbakal \& Filiztekin, 2021). Ottoman court registers have been important primary sources for the inheritance records of individuals during this period. The longevity of these institutions has ensured long-term continuity, that is, the most important characteristic of these particular primary resources. This study has employed inheritance records from different provinces to establish a long-term analysis of wealth distribution. Common problems that emerged from the lack of data, however, have restricted the scope of analysis. Three main problems have played a crucial role in the analysis: (i) probate population, (ii) recordkeeping practices, and (iii) lapses in inheritance records (Ergene et al., 2013, p. 7; Canbakal \& Filiztekin, 2021, p. 2). To minimize the effects of these problems, this study has employed a method based on total mean wealth and Gini coefficients (Shammas, 1978, p. 298). Thus, the discussion is limited to the average wealth levels of socioeconomic groups with an emphasis on longitudinally than regional comparisons and econometric models. 
The findings of this study are related to the recent literature on the causes of the relative backwardness of the Ottoman Empire from the seventeenth century. It is assumed that wealth distribution was more equal in the fastergrowing economies (Van Zanden, 2003). Wealth accumulation is an important determinant of capital formation. It is crucial to keep capital in integrated forms instead of fragmented ones through the rules imposed by the institutional environment. The recent literature argues that relative inequality in wealth distribution and institutional constraints caused low and stagnant economic performances that generated obstacles to the long-run development of Middle Eastern societies (Kuran, 2011). This study, for the first time, provides a critical explicit analysis of these presumptions by presenting long-term wealth distribution from the middle of the seventeenth century to the demise of the Ottoman Empire. The empirical evidence presented within this study suggests that while the Ottoman Empire lagged behind relative to European societies, it had better economic performance than those in the Middle East and Asia. Furthermore, the findings also show that the average wealth of titled individuals was about three or four times higher than those of commoners in the long-term perspective. This rate is more or less the same for each sub-period. The result obtained in the process of comparing the average wealth of titled groups was different from what was expected. The empirical evidence shows that the average wealth of judicial/religious-based groups was higher than that of military/administrative-based individuals until the beginning of the nineteenth century.

The study is organized as follows. The second part reviews the Ottoman economy in an institutional context. This part presents per capita tax revenues and GDP levels of the Ottoman Empire from a comparative perspective. These economic variables in addition to institutional change are crucial to evaluate wealth distribution in a longterm perspective. The third part gives descriptive analysis on average wealth levels by socio-economic groups through primary sources. The limitations of data are also discussed in this part. Finally, the conclusion summarizes the major findings of this study.

\section{THE OTTOMAN ECONOMY IN AN INSTITUTIONAL CONTEXT}

During the pre-industrial period, the institutions based on contractual relations dominated the economic structure of the Ottoman Empire as it was the same in European societies. The Ottomans, however, developed diverse institutional mechanisms regarding its traditional structure. The main aims of administrative bodies were to maximize tax revenues and enhance financial resources to bear the increasing costs of changing economic and political structures. Both European societies and the Ottoman Empire faced exogenous and endogenous shocks as changing military technology, capital inflow from the New World, the discovery of new trade routes as well as changing perceptions of economic actors within the economic environment. Increasing needs for financial resources forced administrative bodies to change their relations with the agents, who were delegated to revenue extracting by the rulers.

The Ottoman Empire employed traditional timar institutions to organize not only economic activities but also political order within the institutional environment. The timar institution was based on contractual relations between the ruler and its agents. The central authority established coalitions with high-ranking bureaucrats, who were members of military organizations of the Ottoman Empire. Each military-based agent could obtain a contract that provided economic privileges in revenue extracting from certain provinces and economic sources. The central authority allocated timar contracts regarding a merit system based on military successes and benefits of agents during military campaigns (Barkan, 1980; Inalc1k, 1994). Contrary to European societies, the central authority granted titles for military-based agents, who were able to obtain timar contracts. In Old Regime France, in particular, elites (families with hereditary titles) dominated the contract market with their financial ability in providing loans for the central authority (Root, 1989; Kiser \& Kane, 2001; Vester, 2004; Balla \& Johnson, 2009).

The central authority had two aims in employing military-based agents instead of landholding aristocracy within the contractual relations. Military-based agents were both less likely to act opportunistically and more loyal to the central authority. The Ottoman Empire, however, developed a multilateral monitoring mechanism to keep its military-based agents honest in contractual relations (Barkan, 1980, p. 286-333). The multilateral monitoring mechanism enabled the central authority to grant different titles to different groups of agents. The judicial/religious-based agents were responsible for monitoring the economic activities of military-based agents, and more importantly, this group of agents generated the highest authority (kadi) as a representative body within the legal structure. The laws were enforced through the highest judicial/religious-based agents in Ottoman courts. The central authority also employed state officials in collecting different taxes and auditing the economic activities 
Süleyman Demirel Üniversitesi Vizyoner Dergisi, Yıl: 2022, Cilt: 13, Sayı: 33, 236-253.

Süleyman Demirel University Visionary Journal, Year: 2022, Volume: 13, No: 33, 236-253.

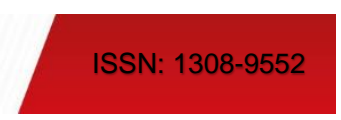

of military-based agents. Finally, the central authority forced military-based agents to participate in military campaigns in exchange for granted economic privileges. The central authority could directly control the economic activities of military-based agents.

Table 1. Per Capita Tax Revenues (In Silver, Ottomans 1500=100)

\begin{tabular}{ccccccccc}
\hline Years & England & France & Spain & Venice & Austria & Russia & Prussia & Ottomans \\
\hline $1500 / 49$ & 73 & 95 & 171 & 367 & & & & 100 \\
$1550 / 99$ & 119 & 145 & 255 & 395 & & & & 104 \\
$1600 / 49$ & 203 & 242 & 834 & 501 & & & 32 & 63 \\
$1650 / 99$ & 516 & 754 & 763 & 567 & 141 & & 119 & 89 \\
$1700 / 49$ & 1226 & 580 & 381 & 618 & 208 & 83 & 328 & 113 \\
$1750 / 99$ & 1455 & 650 & 616 & 483 & 307 & 199 & 709 & 95 \\
$1800 / 49$ & 8791 & 4422 & 2169 & 188 & 1694 & 1315 & 2306 & 695 \\
$1850 / 99$ & 3634 & 4671 & 2724 & & 2893 & 1287 & 2488 & 987 \\
$1900 / 13$ & 6035 & 6679 & 2840 & & 4760 & 1733 & 5256 & 1301 \\
\hline
\end{tabular}

Source: These data are derived from various sources. See, Genç and Özvar (2006), Karaman and Pamuk (2013), Brandt, Ma, and Rawski (2014), Ma and Rubin, (2019).

The traditional timar institutions and their mechanisms allowed the Ottoman Empire to rapid territorial expansion during the sixteenth century. The central authority achieved to finance a large army without reserving substantial shares from the central budget. Each military-based agent had the right to crop a share from tax revenues they collected in exchange for providing provisions and training new troops for the military organization (Genç, 2000, p. 101). In terms of per capita tax revenues, the economic performance of the Ottoman Empire was close to other societies during the sixteenth century (Table 1).

The seventeenth century was a period of transformations particularly within the institutional structure due to the exogenous shocks and endogenous dynamics. The capital inflow from the New World and changing military technology were the main exogenous shocks that forced the Ottoman economy to change from the last decades of the sixteenth century (Tezcan 2010). It could be presumed that exogenous shocks deteriorated institutional mechanisms that organized the allocation of contracts and multilateral monitoring mechanisms. The territorial expansion started to slow down when the military technology became insufficient to overcome the well-equipped regular armies of European societies. The most important economic outcome emerged in the allocation of contracts toward military-based agents. In terms of modern economics, the contract market faced a shortage problem from the last decades of the sixteenth century. While granting titles was the dominant strategy of the central authority to sustain economic and political order, individuals directed their interests to be members of military-based agents or judicial/religious-based agents to enjoy higher economic returns under the domination of traditional timar institutions. As long as the Ottoman Empire enhanced its territories, the demand for titles and timar contracts grew in substantial proportions. When Ottoman expansion reached its natural limits, the shortage problem deteriorated the institutional mechanisms and changed the perception of agents. In other words, exogenous shocks entailed endogenous problems that forced the Ottoman Empire to change the institutional structure from the beginning of the sixteenth century.

The first outcome of exogenous shocks was devaluations in Ottoman currencies (Pamuk, 2000). The central authority decreased the silver content of akche from the last decades of the sixteenth century. Military-based agents cropped higher shares from tax revenues to finance their increasing costs due to the devaluations while the state revenues decreased during the same period. Secondly, military-based agents suffered from increasing costs due to the long-distance campaigns. When the shortage emerged in the contract market, the central authority allocated new timar contracts from different regions that were far from Western Anatolia and Balkan territories. Thus, the military-based agents abstained from military campaigns that decreased the military power of the Ottoman Empire. Thirdly, and more importantly, military-based agents started to direct their financial resources to obtain timar contracts by the by-passing merit system. Directing financial resources to obtain contracts instead of benefiting in wars became the dominant strategy due to its low risk under the timar institution. Thus, the Ottoman Empire faced two main problems: violence and low financial resources. The Jalali Revolts deteriorated not only the military 
organization but also agricultural production during the first half of the seventeenth century (Darling, 1996, p. 23; Barkey, 1994). The reflection of endogenous factors was decreasing per capita tax revenues during the seventeenth century (Table 1). The most important but least noticeable result of these riots was the changes in the structure and dominance of the agents in which military-based agents were surpassed by judicial/religious-based agents and provincial notables with different titles from the seventeenth century (Rubin, 2017). Even if military-based agents existed within the political and economic environments, their wealth reversed and lagged behind the wealth of judicial/religious-based agents until the nineteenth century.

The central authority mitigated increasing costs of violence and opportunistic behavior agents by changing its institutional structure called the tax-farming (iltizam) institution from the last decades of the sixteenth century. The main purpose of the central authority was to increase its financial resources in short-terms and sustain political order within the territories. The tax-farming institution was based on contractual relations as it was the same under the timar institution. The small institutional differences, however, entailed economic divergence from European societies from the beginning of the seventeenth century (Table 2).

Table 2. The Ottoman Economy in Global Perspective: Per Capita GDP Levels, 1500-1913

\begin{tabular}{|c|c|c|c|c|c|c|c|c|c|c|c|}
\hline \multicolumn{12}{|c|}{ Absolute Values } \\
\hline 1500 & 1600 & 1700 & 1750 & 1820 & 1840 & 1870 & 1880 & 1890 & 1907 & 1911 & 1913 \\
\hline 600 & 600 & 632 & 648 & 740 & 789 & 952 & 858 & 1056 & 1020 & 909 & 1407 \\
\hline \multicolumn{12}{|c|}{ Relative Values $($ World $=100)$} \\
\hline 106 & 101 & 103 & 105 & 111 & 118 & 109 & 99 & 121 & 81 & 72 & 92 \\
\hline \multicolumn{12}{|c|}{ Europe $=100$} \\
\hline 78 & 68 & 64 & 65 & 62 & 53 & 49 & 53 & 43 & 47 & 40 & 41 \\
\hline \multicolumn{12}{|c|}{ Middle East $=100$} \\
\hline 102 & 102 & 107 & 113 & 122 & 134 & 129 & 119 & 146 & 102 & 91 & 135 \\
\hline \multicolumn{12}{|c|}{ Asia $=100$} \\
\hline 106 & 105 & 110 & 113 & 127 & 129 & 172 & 117 & 154 & 114 & 95 & 202 \\
\hline
\end{tabular}

Source: Maddison 2001; 2003. * indicates East Asia includes Japan, China, India, and Indonesia, ** indicates West Asia includes Iraq and Iran, GDP and per capita GDP levels are in terms of 1990 US Dollars. For more information about absolute values of per capita GDP levels, see Bulut and Altay (2021).

The central authority delegated agents in tax collecting by allocating tax-farming contracts. Instead of a merit system, an auction mechanism determined the price of contracts that were committed by the agents (mültezims) in contractual relations (Darling, 1996, p. 119; Çizakça, 1996, p. 140; Salzmann, 2004, p. 113). In other words, each agent offered a price, and central authority delegated the highest bidder as an agent in state offices. Another small institutional difference emerged in contract durations. The military-based agents had the right to manage timar contracts as long as they served within the military organization. The tax-farming contracts, however, had a limited contract duration from one year to 12 years (Salzmann, 1993, p. 339; Darling, 1996, p. 135; Karaman \& Pamuk, 2010, p. 601). Multilateral monitoring deteriorated due to the changing structure of agents toward private entrepreneurs. The judicial/religious-based agents had the authority to control the economic activities of agents, and the other two mechanisms were extinguished under the tax-farming institution. In other words, the level of trust and cooperation that was established among the central authority and its military-based agents decreased with the changing structure of agents. The emergence of more complex contractual relations allowed contracting parties for opportunistic behaviors under the new institution structure.

The complex contractual relations, however, entailed increasing transaction costs within the institutional environment. The limited duration contracts directed agents to maximize their revenues in the short term. The central authority was compulsory to increase its financial resources in the short term due to the exogenous shocks. The tax-farming contracts enabled the central authority to terminate contracts by using its coercive power. The changing structure of agents from military-based agents to provincial notable decreased risks in favor of the central authority when it chose to renege (müsadere) on contracts (Arslantaş, 2019). The new group of agents, however, preferred to behave opportunistically to recover their investments on tax-farming contracts. Limited contract 
durations and increasing confiscatory behavior of the central authority created such incentives for the agents within the institutional environment.

Figure 1. The Trend of Average Budget Deficits by Sub-Periods (In Silver, 1500/49=100)

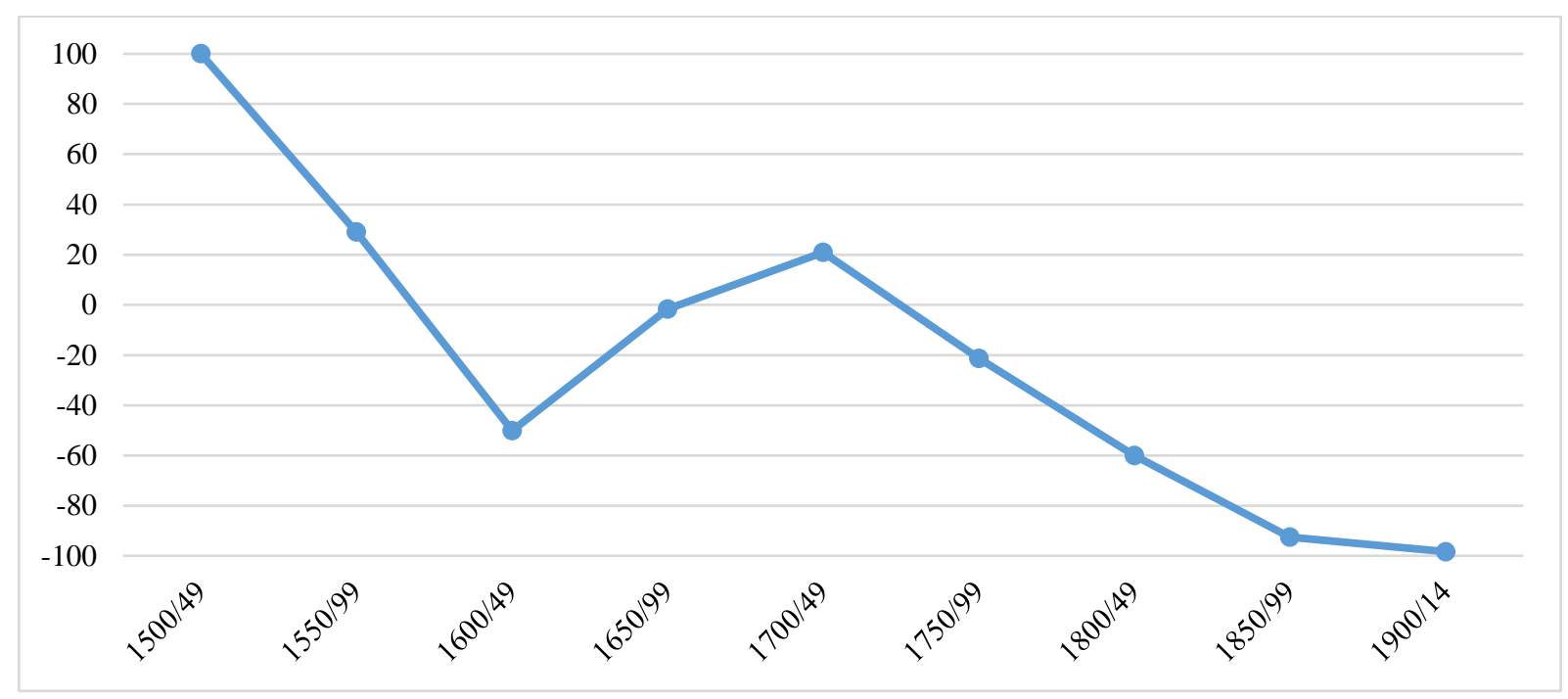

Source: This figure is generated from Genç \& Özvar (2006).

The failure of tax-farming institutions entailed higher budget deficits during the first half of the seventeenth century. In the second half of the century, budget deficits decreased when the effects of the Jalali Revolts started to diminish in the Ottoman economy. The central authority imposed new rules over the tax-farming institution. The main purpose was to direct agents to invest in their contracts and to increase financial resources during the eighteenth century (Genç, 2000, p. 113). The first change was increasing contract durations for the lifetime of agents. As long as the agents lived, they had the right to manage contracts under the lifetime tax-farming institution. The increasing durations entailed the emergence of a new kind of payment for the central budget. The agents had to pay an advance payment (muaccele), which was 10 or 12 times higher than annual payments in tax-farming contracts (Genç, 2000, p. 108; Karaman \& Pamuk, 2010, p. 602). Even if the central authority enforced long-term contracts with advance payments from the beginning of the eighteenth century, budget deficits continued to increase until the nineteenth century (Figure 1). Although advance payments increased financial resources during the first decades of the century, the central authority imposed confiscatory behaviors with its coercive power and the competition among provincial notables deteriorated the expected benefits of long-term contracts in the Ottoman Empire (Genç, 2000, p. 115). The nineteenth century was the period for major economic, political, and institutional changes that promoted centralization in the Ottoman Empire (Yaycioğlu, 2016). These reforms absorbed a substantial proportion of financial resources although per capita tax revenues increased six times higher than earlier centuries. The key was the decreasing role of judicial/religious-based agents within the institutional environment, and administrative/military-based agents started to dominate state offices from the nineteenth century.

What was the effect of changing institutions on individual wealth in the Ottoman Empire? The abolition of military-based agents showed that judicial/religious-based agents dominated the economic and political environment in the Ottoman Empire. Provincial notables as commoners started to appear in contractual relations with political supports of judicial/religious-based agents as well as financial supports of non-Muslim financiers (Inalc1k, 2017, p. 38). The confiscatory behavior of the central authority forced these agents to direct their financial resources toward private organizations (Waqfs). The court records, however, included inheritance records of individuals from different socio-economic groups. Institutional change affected not only economic performance but also the role of socio-economic groups in the economic and political structures of the Ottoman Empire. The changes in individual wealth by socio-economic groups provided historical evidence on why the Ottoman Empire lagged behind European societies even before industrialization. The changing structure of bargaining groups allowed the central authority to prevent powerful groups from limiting coercive power for the long term. 


\section{SOCIOECONOMIC GROUPS, INDIVIDUAL WEALTH, AND INEQUALITY}

\subsection{Data and Source}

Our analysis of individual wealth in the Ottoman Empire relies on data from the court records of 36 different provinces. The inheritance records of individuals from different socio-economic groups include considerably sufficient data, providing an adequate setting for this study. To establish data sets of individual wealth, this study employs 84 different court records and 4.463 inheritance records, covering more than 250 years with lapses (Appendix). The records located in the National Library of Turkey and the Turkey Diyanet Foundation Center for Islamic Studies (ISAM) provide primary sources for Ottoman inheritance records from the middle of the seventeenth century. Since the earliest records contain inheritance records more sporadically, this study utilizes records from later periods.

This study has chosen court records randomly in the first stage. Employing court records from the same city as earlier literature has reflected average wealth levels with deviations. Contrary to this method, incorporating different cities with diverse scales has higher ability to obtain average wealth levels for the Ottoman Empire. For instance, although the literature focused on Kastamonu has argued the effects of exogenous shocks on changing average wealth levels during the eighteenth century, average wealth levels are insufficient to represent average wealth levels of the entire Ottoman Empire (Coşgel \& Ergene, 2012). Another study based on individual wealth levels that has included seven different cities (Bursa, Kayseri, Manisa, Antep, Trabzon, Manastır, Diyarbakır) has deficiencies to show average wealth levels of the Ottoman Empire (Canbakal \& Filiztekin, 2021). The reason is that this specific research has employed similar cities with similar scales. Such method has caused to emerge higher average wealth levels for the Ottoman Empire than they should be. The key difference of this study is that it employs cities of different scales. As mentioned above, including small-scale towns has allowed to obtain average wealth levels with small deviations.

In the second stage, this study has employed inheritance records that included only dellaliye costs in inheritance records. A well-known practice of keeping inheritance records is that each record was mostly generated by willing of inheritors. Primary sources have indicated that courts determine the total wealth of deceased individuals through their monetary and nonmonetary assets. As it can be understood that determining values of nonmonetary assets was up to court officials. Dellaliye costs have meant that court assigned an official to determine market prices of nonmonetary assets in order to obtain total wealth. Inheritance records have also included different costs in determining total wealth. Furthermore, these records have also provided information about borrowing and lending relationships of deceased individuals. If there is a debt to third parties, it is deducted from the total wealth. On the other side, if there is a receivable in inheritance records, it is added on the total wealth. The court has practiced such transactions in order to obtain net wealth, yekun. Thus, this study has used this item, yekun, that deflated court costs as well as lending-borrowing amounts.

In the third stage, this study has employed Istanbul Consumer Price Index (ICPI) to deflate nominal values that given under the item of yekun. Furthermore, this study has also converted wealth levels into silver to execute analysis in real values. Silver contents of akche and qurush are available for the Ottoman Empire. Although converting currencies into silver has allowed us to show monetary values in the same way, these have reflected nominal values. Thus, ICPI is used to obtain real values in terms of silver. Hence, the average wealth levels given in following tables shows silver values in real terms.

Prepared by Ottoman courts, inheritance records have provided information about not only the wealth of individuals but also their socioeconomic structure, including titles, father's title, occupations, properties, inheritors, and debts left behind. (Ergene et al., 2013, p. 7). This study, however, focuses on titles of individuals, and aggregate wealth levels that included both movable and immovable assets, including cash, real estate, and other items listed by court officials. Regular inheritance records provide information about the socioeconomic structure of individuals (see Tables 3 and 4). 
Süleyman Demirel Üniversitesi Vizyoner Dergisi, Yıl: 2022, Cilt: 13, Sayı: 33, 236-253.

Süleyman Demirel University Visionary Journal, Year: 2022, Volume: 13, No: 33, 236-253.

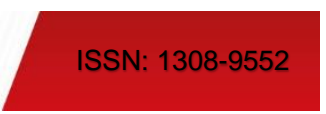

Table 3. An Example for Titles of Individuals

\begin{tabular}{ccccccc}
\hline & Year & Name & Title & Father's Name & Father's Title & City \\
\hline 1 & 1798 & Osman & Agha & Mehemmed & Agha & Tokat \\
2 & 1731 & Mehmed & Agha & Şahin & Commoner & Vidin \\
3 & 1769 & Halil & Effendi & Ali & Agha & Antep \\
4 & 1777 & Mehmed & Effendi & Ahmet & Effendi & Amasya \\
5 & 1732 & Hasan & Commoner & Mustafa & Commoner & Manisa \\
6 & 1768 & Bagos & Commoner & Serabiyan & Commoner & Tekirdağ \\
\hline
\end{tabular}

Source: BOA, Tokat Court Record 3/47/1 for Osman Agha; BOA, Vidin Court Record 10/84/1 for Mehmed Agha; BOA, Antep Court Record 131/96/48-50 for Halil Efendi; BOA, Amasya Court Record 57/6 for Mehmed Efendi; BOA, Manisa Court Record 189/51/83 for Hasan; BOA, Tekirdağ (Rodoscuk) Court Record 1751/45/1b for Bagos. *BOA: General Directorate of State Archives, Department of Ottoman Archives.

Table 3 presents a sample that shows socioeconomic structures of deceased individuals from their inheritance records. Each record is belonging to different regions of the Ottoman Empire. These six inheritance records appear to have been created in the eighteenth century. The sample presents names of deceased individuals with their titles. Inheritance records include titles as it is given in column four. Following the socioeconomic status, documents also present names and titles of deceased individual's father as given in Table 3. These records provide information for estimating average wealth levels by socioeconomic status. More importantly, the information given inheritance records suggest that there was an established culture in legal practices in which longevity of inheritance records emerged in the Ottoman Empire.

Table 3 also presents two main titles that were common in Ottoman society. The recent literature argues that individuals titled with Agha were the wealthiest and highest-ranking members of the military/administrative-based agents and individuals titled Effendi represented the wealthiest and most prestigious groups in judicial/religious agents in the Ottoman Empire (Ergene \& Berker, 2009; Coşgel \& Ergene, 2012, p. 317). The data presented in Table 4 shows that the wealth of titled individuals was higher than those of commoners. Contrary to this expected outcome, one particular case dated 1731 provides an attractive finding in individual wealth levels. As Metin Coşgel and Boğaç Ergene (2012) argue that titled individuals whose father had a title also held higher wealth levels during the eighteenth century. Even if this survey is limited to a single city, this finding indicates an expected phenomenon. What makes this particular case unusual is that Mehmed Agha had substantial wealth compared to other cases, while his father was a commoner in Ottoman society. This probably results from the fact that Mehmed Agha might have risen to important ranks in the military organization. In addition, it can be expected that Mehmed Agha's father could have been an important merchant or craftsman in Vidin, which was one of the most important cities in the European regions of the Ottoman Empire.

Table 4. A Sample of Individual Wealth and Shares of Descendants*

\begin{tabular}{ccccccccc}
\hline & $\begin{array}{c}\text { Numbers of } \\
\text { Inheritors }\end{array}$ & $\begin{array}{c}\text { Numbers of } \\
\text { Children }\end{array}$ & Wife & $\begin{array}{c}\text { Numbers } \\
\text { of Other } \\
\text { Inheritors }\end{array}$ & $\begin{array}{c}\text { Wealth of } \\
\text { Individuals } \\
\text { (in qurush) }\end{array}$ & $\begin{array}{c}\text { Shares of } \\
\text { Children }(\%)\end{array}$ & $\begin{array}{c}\text { Shares of } \\
\text { Wife (\%) }\end{array}$ & $\begin{array}{c}\text { Shares of other } \\
\text { Inheritors (\%) }\end{array}$ \\
\hline 1 & 2 & 2 & - & - & 9.106 & 68 & - & - \\
2 & 4 & 3 & 1 & - & 355.660 & 66 & 9 & - \\
3 & 13 & 11 & 2 & - & 39.597 & 31 & 4 & - \\
4 & 4 & - & 1 & 3 & 8.000 & - & 20 & 60 \\
5 & 4 & 3 & 1 & - & 1.153 & 79 & 11 & - \\
6 & 4 & 3 & 1 & - & 1.167 & 87 & 13 & - \\
\hline
\end{tabular}

* indicates that the order of inheritance records is the same given in table $3 .{ }^{\mathrm{N}}$ indicates that wealth levels in column 5 show nominal values in terms of Ottoman qurush.

Table 4 gives another important piece of data about deceased individuals. Each inheritance record includes information about inheritors and their shares from the fortune. The data presented in Table 4 indicates that while children and wife(s) formed the main inheritors of the fortune in records, there were other inheritors from relatives of deceased individuals. One particular case dated 1777 should be sufficient to demonstrate such examples. The inheritance record of Mehmed Effendi, son of Ahmet Effendi, indicates that the spouse inherited 20 percent of his 
wealth, while his brother's children inherited 60 percent. As can be seen in Table 4, the other 20 percent of the wealth is not inherited by any heir. It should be assumed that the rest of the wealth was allocated for different purposes. The inheritance records allow us to present three main financial exchanges that consumed the rest of the wealth after it was inherited among inheritors. The first is court costs that should be paid from the wealth of deceased individuals (Ergene, 2002). Secondly, inheritance records include the debts of the deceased individuals to third parties that were paid from the wealth. Finally, it is known that one of the most common traditions, establishing waqfs, directed individuals to transfer a certain amount of their wealth towards these private organizations. For these reasons, it can be accepted as a common practice not to share the entire wealth among the heirs.

One particular case dated 1768, however, indicates a different practice. The inheritance record of Bagos, son of Serabiyan, a non-Muslim Ottoman subject, shows that all the wealth was shared among the heirs. This may have emerged from two different reasons related to the former ones. First of all, the fact that the inheritor was a nonMuslim might have caused the court costs to not be collected. Secondly, this individual might not have any debts to third parties. Inheritance records used within this study, in fact, provide sufficient sources for us to examine these issues in more detail. To limit the scope of this analysis with the average wealth levels of different socioeconomic groups, these issues will be subjected to future research.

To prepare our dataset, however, we employ two main economic variables to examine individual wealth in the long-term perspective. The first is average wealth levels by sub-periods covering the 50-year periods. Each inheritance record gives the aggregate wealth of individuals, including the capital, real-estates, and inventories. The values are nominal. Although the Ottoman qurush is widely used as monetary values, it is also possible to see different currencies as akche and para in the records. To deflate nominal values, we convert all values to silver by employing the silver content of Ottoman currencies established by Şevket Pamuk (2004b, p. 455). The main aim of this transaction is to simplify calculating real values of average wealth levels. Secondly, this study uses Istanbul Consumer Price Index (ICPI) in deflating nominal values (Özmucur \& Pamuk, 2002, p. 301). Süleyman Özmucur and Pamuk (2002) present the ICPI in 10-year periods from the middle of the fifteenth century to the first decades of the twentieth century. We, however, derive 50-year average indexes from these data in terms of silver. One can question why silver values were used instead of Ottoman currencies. The main reason has two aspects. First, as will be discussed later, this study does not provide an absolute estimate of wealth. Instead, it presents a trend of average wealth values and a comparative analysis across socioeconomic groups. Therefore, the values given are not an absolute estimate of individual wealth considered for the Ottoman Empire. Secondly, presenting these analyses in terms of silver facilitates the display of the data. Using values in terms of Ottoman qurush and akche entails the emergence of too many digits due to the large decimal numbers. Recall that this study utilizes average wealth values to compare economic conditions of diverse socioeconomic groups and sub-periods. Thus, each value presented in related tables is in terms of silver.

\subsection{The Limitations of Data}

This study and its findings are based on historical data. Inheritance records located in Ottoman court registers have generated the main primary sources of the analysis. Employing self-created historical data has limited the scope of economic analysis through individual wealth levels. There have been three common problems that restrict to conduct of a comprehensive analysis on wealth and its distribution within the economic environment. In addition to these problems, this study has presented another important problem that affects major findings. This problem is based on a lack of data instead of a methodological one. Before focusing on this problem, this part has summarized the effects of common problems on the findings of this study. The reason why this part has been presented before the findings are to emphasize that the estimates and discussions given in the next part should be evaluated within these limitations.

The first problem has emerged from the incongruity between the numbers of inheritance records and the population of the province. One rough estimate has been made by Pamuk (2010, p. 150) has indicated that the ratio of inheritance records to total deaths was below 10 percent in the Ottoman Empire. Carole Shammas (1978, p. 297) has argued that one of the main problems in using inheritance records is that the population failed to leave their wills and inventories, and richer groups mostly refrained from the legal process. Each discussion, in fact, has provided an important understanding of the research depended on inheritance records from historical perspectives. Inheritance records have failed to provide sufficient sources to estimate absolute individual wealth, particularly for early-modern societies. One particular case dated 1670 should be sufficient to show this problem. According 
to the Konya court records, there is only one inheritance record for the year 1670. (BOA, Konya Court Register, 18/1). This situation shows that the number of deaths was not low, but that the application to the court for inheritance registration stayed at the low levels. In this sense, the wealth derived from this document cannot reflect neither a socioeconomic group nor the average amount of wealth in the Ottoman Empire. More importantly, it is difficult to find out if there are other Konya court records on the same date. To minimize the effects of such problems, this study employs inheritance records of different regions that had similar economic conditions with seventeenth-century Konya. By combining different regions, this study utilizes average wealth levels for each subperiod. Thus, the same method is conducted for other sub-periods.

The second problem is based on legal practices in recording wills and inventories of deceased individuals in the Ottoman Empire. The recent literature indicates that Ottoman courts recorded wills and inventories of deceased individuals by assets and their prices (Pamuk, 2010; Ceylan, 2016; Canbakal \& Filiztekin, 2021). The pricing of inventories causes estimation problems in wealth analysis. Even if this pricing is one of the most important legal practices in Ottoman courts, it is difficult to consider this process is sufficient to reflect individual wealth. Pamuk (2010, p. 148) has discussed that inventories that were presented to a court may be incomplete or there may be a pricing bias that determines the value of inventories. Pinar Ceylan (2016) offers one of the most comprehensive studies in this regard. This research argues that even if prices of certain inventories based on foodstuff had reflected market values, determining prices of non-food items and second-hand goods could be problematic in estimating wealth levels. The inheritance records of different individuals from different regions present exactly the same nonfood items with different prices. However, there is no method for why these price differences occurred or how the calculation was made by court officials. In this sense, this study agrees with the arguments presented in the recent literature, that is, inheritance records may be insufficient to reflect the real wealth of individuals. As mentioned above, this problem emerges from legal practices that direct us to employ average wealth levels to minimize the effects of the second problem.

The third fundamental problem is that the data contains temporal gaps. This makes it difficult to establish a time series for a specific region from a long-term perspective. Establishing regional comparisons becomes compelling under the self-created historical dataset. Up to now, the most common method used to fill temporal gaps is to include data from similar regions in the analysis. This method, however, entails deviations in values of individual wealth. Many factors determine the wealth of individuals. Geographical location, climatic differences, and even distance from major cities differentiate individual wealth, even if different regions with similar characteristics are included (Alfani at el., 2014). Thus, deviations in the average wealth values used should be considered in the analysis. More importantly, these deviations may also cause the Gini coefficients to be higher than they should be. In this sense, higher Gini coefficients generate the fourth problem that emerged from the limitations of the data. One should assume that these coefficients presented in this study should be at least 0.10 points lower than they should be. (Table 5 and 6). In this sense, this study focuses on an analysis of long-term economic changes over these coefficients, rather than presenting a distribution analysis on the Gini coefficients. The following section presents the analysis carried out on the method and data used within these data limitations.

\subsection{An Empirical Analysis on Individual Wealth in the Ottoman Empire}

The analysis presented in this part has a dual aim. The first is to present an analysis of individual wealth concerning institutional change context. The limitations of data have limited the scope of this analysis. Proposed reasons for establishing data through court records have restricted the use of economic variables in a comprehensive wealth analysis. To minimize the limitations of data, we first employ average mean wealth to establish a comparative analysis among different welfare groups. In this sense, wealth groups have been divided into four quartiles. Even if these wealth estimates have failed to show absolute individual wealth in different periods, the differences between quartiles have provided sufficient information on wealth distribution (Pamuk, 2010; Ergene \& Berker, 2009; Coşgel \& Ergene, 2011, 2012; Ergene et. al., 2013). A similar method has also been suitable for comparing average wealth levels of titled and untitled individuals. The second is to discuss wealth distribution through a Lorenz curve and Gini coefficients. As mentioned in the previous part, the Gini coefficients presented in this study may be higher than they should be. These Gini coefficients, however, have provided adequate information to establish a comparison among different sub-periods. Thus, this part has presented a long-term analysis of these two main aims. 
Süleyman Demirel Üniversitesi Vizyoner Dergisi, Yıl: 2022, Cilt: 13, Sayı: 33, 236-253.

Süleyman Demirel University Visionary Journal, Year: 2022, Volume: 13, No: 33, 236-253.

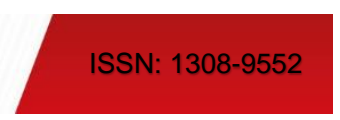

Table 5. Individual Wealth by Periods (in kgs. of Silver)

\begin{tabular}{lcccccc}
\hline Variables & $\mathbf{1 6 5 0 / 9 9}$ & $\mathbf{1 7 0 0 / 4 9}$ & $\mathbf{1 7 5 0 / 9 9}$ & $\mathbf{1 8 0 0 / 4 9}$ & $\mathbf{1 8 5 0 / 9 9}$ & $\mathbf{1 9 0 0 / 1 8}$ \\
\hline Gini & 0.56 & 0.64 & 0.62 & 0.63 & 0.58 & 0.59 \\
Top \% 10 & 20.24 & 146.83 & 36.33 & 22.10 & 15.66 & 61.53 \\
First \% 25 & 13.76 & 67.53 & 8.24 & 11.48 & 8.15 & 31.44 \\
Second \% 25 & 3.48 & 4.90 & 2.51 & 1.73 & 1.45 & 2.84 \\
Third \% 25 & 1.88 & 1.76 & 1.24 & 0.72 & 0.75 & 1.09 \\
Fourth \% 25 & 0.80 & 0.56 & 0.56 & 0.22 & 0.33 & 0.42 \\
Average & 5.22 & 18.76 & 5.68 & 3.54 & 2.67 & 9.07 \\
$\mathrm{~N}$ & 30 & 247 & 439 & 2257 & 1333 & 157 \\
\hline
\end{tabular}

Table 5 presents aggregate estimates on individual wealth by different quartiles and Gini coefficients from the middle of the seventeenth century to the end of the First World War. We calculated average wealth levels by deducting debts of deceased individuals to third parties and court costs that have to be paid. The data presented in table 5 can be evaluated in three domains. The first is the trend of Gini coefficients in the long-term perspective. The lowest Gini coefficient has emerged during the second half of the seventeenth century. In the following periods, these coefficients have tended to increase for 200 years. The lowest coefficient, however, may emerge due to the small observation compared to other periods. In an institutional context, the changes in the Gini coefficient may emerge due to the institutional change, particularly in tax-farming contracts. Gini coefficients presented in Table 5 are also close to the findings of one particular research that focused on the eighteenth-century Kastamano town of the Ottoman Empire (Coşgel \& Ergene, 2012, p. 314).

The emergence of new contractual relations entailed the participation of different groups in economic exchanges with the central authority. The central authority employed administrative/military-based groups in contract relations under the timar institution. As long as the Ottoman Empire sustained its military achievements, these contracting parties were able to enjoy higher economic returns from timar contracts. This probably created an incentive mechanism for subjects to become a member of the military organization instead of participating in different economic activities. The timar institution included a reward mechanism that provided not only a contract but also honorific titles of individuals. The abandonment of this institutional structure in favor of tax-farming institutions caused changes in the structure of agents. Provincial notables without any title and non-Muslims started to involve in contractual relations. In other words, shares of titled individuals in the contract market started to decline from the second half of the seventeenth century. The contract market, however, failed to establish a fair allocation in taxfarming contracts. Powerful groups, including both administrative/military-based agents and judicial/religiousbased agents, dominated the contract market by establishing collusion among each other. Provincial notables had become sub-contractors or secondary agents within the institutional structure. In this sense, a substantial share of gains from contractual relations was absorbed by these primary agents. In this sense, expected future revenues of secondary agents, including provincial notables and local groups, had decreased from the middle of the seventeenth century. Per capita tax revenues provided historical evidence as an outcome of institutional change (Table 1). There was also a constant trend in per capita GDP levels of the Ottoman Empire during the same period (Table 2). These changes in contractual relations could deteriorate wealth distribution as it could be seen in Gini coefficients until the middle of the nineteenth century. In the last two sub-periods, however, Gini coefficients started to decrease which showed efficient wealth distribution in the Ottoman economy. This probably resulted from the fact that political transformations and reforms towards centralization had organized better wealth distribution from the second half of the nineteenth century. Substantial growth rates of per capita GDP and tax revenues had shown a positive relationship between better economic performance and wealth distribution in the Ottoman Empire (Table 1 and 2).

Secondly, this study employs average wealth levels that have lowered the effects of scattered observations numbers, following the Gini coefficients. Increasing numbers in observations cause different average wealth levels, particularly for the wealthiest 25 percent. The other three quartiles have more stable average wealth levels. This probably results from the fact that the richest groups might have escaped from revealing their wills and inventories. If one chooses to use the information presented for the wealthiest 25 percent, this may be misleading in examining the average wealth levels of the Ottoman Empire. The outcomes are as expected. There are significant gaps between the wealthiest groups and others in terms of average wealth levels. These gaps may emerge from including titled groups, who had 
extraordinary revenues because of their reputation and honorific titles. However, their numbers are limited within the dataset. This gap, however, provides historical evidence that shows economic differences between the wealthiest groups and ordinary individuals. The other three quartiles, starting the second wealthiest 25 percent, allow us to make an examination about the economic performance of the Ottoman Empire in the long-term perspective. What makes these quartiles are important is that these average wealth levels reflect a sample of the population. As it can be understood that population of individuals with honorific titles was in very small numbers in the Ottoman Empire. The rest, including non-honorific titles and commoners, generates a substantial part of the Ottoman population.

Average wealth levels of the last three quartiles indicate a U-shaped pattern that may signal the economic performance of the Ottoman Empire in the long-term perspective. The findings given in Table 5 suggest that there was an economic stagnation from the eighteenth century to the middle of the nineteenth century. The average wealth levels of the last three quartiles show a growing pattern in the last two sub-periods. This probably results from the fact that political reforms and economic transformations had a positive effect on the Ottoman economy. On the eve of the First World War, average wealth levels of the last three quarters have converged to the values in the second half of the seventeenth century. As mentioned above, increasing per capita GDP and tax revenues are compatible with the findings presented in Table 5. Furthermore, overall average wealth levels have the same pattern in the long term. These findings are also compatible with the institutional change process.

The eighteenth century was the period of major transformations in the political, economic, and social structures of the Ottoman Empire. The emergence of lifetime tax-farming contracts allowed powerful groups to enhance their political and economic influence in regions of the Ottoman Empire. In other words, the decentralized political structure had deepened under the lifetime tax-farming institution. The key was that powerful groups had the power to assign their secondary agents or provincial notables towards state offices. By doing this way, both administrative/military-based and judicial/religious-based agents had the tools to deteriorate the multilateral monitoring mechanism of the central authority. The increasing financial needs also forced the central authority to turn a blind eye to the actions of these groups. In fact, there was increasing negotiations and bargaining among the central authority and its agents. As Mehmet Genç (2000), one of the earliest scholars focused on the role of lifetime tax-farming institutions, had argued that even if these contracts increased state revenues in the short run, the system had failed during the eighteenth century. Not only per capita GDP and tax revenues but also the findings presented in Table 5 shows quantitative outcomes of the effects of institutional change.

Table 6. Individual Wealth by Socioeconomic Groups (in kgs. of Silver)

\begin{tabular}{|c|c|c|c|c|c|c|}
\hline Variables & $1650 / 99$ & $1700 / 49$ & $1750 / 99$ & $1800 / 49$ & $1850 / 99$ & $1900 / 18$ \\
\hline \multicolumn{7}{|c|}{ Titled Individuals } \\
\hline Gini & 0,48 & 0,72 & 0,63 & 0,63 & 0,60 & 0,67 \\
\hline Top \% 10 & 21.72 & 165.03 & 77.10 & 45.23 & 33.16 & 105.6 \\
\hline First $\% 25$ & 17.03 & 82.26 & 39.68 & 25.09 & 17.34 & 59.94 \\
\hline Second $\% 25$ & 6.71 & 7.98 & 5.61 & 4.34 & 3.43 & 6.32 \\
\hline Third \% 25 & 2.06 & 2.26 & 2.32 & 1.71 & 1.65 & 1.92 \\
\hline Fourth \% 25 & 1.46 & 0.61 & 0.71 & 0.44 & 0.58 & 0.59 \\
\hline Average & 7.70 & 23.48 & 12.23 & 7.90 & 5.74 & 17.48 \\
\hline $\mathrm{N}$ & 17 & 111 & 149 & 451 & 295 & 58 \\
\hline \multicolumn{7}{|c|}{ Untitled Individuals } \\
\hline Gini & 0,37 & 0,66 & 0,54 & 0,56 & 0,51 & 0,59 \\
\hline Top \% 10 & 4.03 & 119.06 & 8.30 & 14.28 & 9.40 & 23.27 \\
\hline First \% 25 & 3.51 & 54.17 & 5.45 & 7.60 & 5.06 & 13.33 \\
\hline Second $\% 25$ & 2.13 & 3.36 & 2.11 & 1.39 & 1.16 & 1.94 \\
\hline Third \% 25 & 0.77 & 1.57 & 1.15 & 0.62 & 0.69 & 0.89 \\
\hline Fourth \% 25 & 0.45 & 0.53 & 0.54 & 0.20 & 0.30 & 0.42 \\
\hline Average & 1.98 & 14.91 & 2.31 & 2.45 & 1.80 & 4.13 \\
\hline $\mathrm{N}$ & 13 & 136 & 290 & 1806 & 1038 & 99 \\
\hline
\end{tabular}


As mentioned above, similar methods and economic variables are imposed to compare the average wealth levels of different socioeconomic groups in the Ottoman Empire. We have calculated Gini coefficients and average wealth levels presented in Table 6 with the same method. To prepare our dataset, we have divided our sample of inheritance records into two samples compared to titled and untitled individuals and have examined them separately. In comparing titled and untitled individuals, there are also limitations of data in addition to presented in the previous part. Inheritance records have provided information about the titles of individuals. However, there is no information about whether these titles are honorific or not. Some of these titles may have been given to individuals by the local people as respect. It is difficult to separate these titles from the existing information of primary sources. Thus, the sample of titled individuals has included all individuals with a title. This probably has caused lower average wealth levels of untitled individuals than they should be.

In terms of average wealth levels, the findings indicate a U-shaped pattern, particularly for the last three quartiles of both socioeconomic groups. When the institutional context is considered, these findings are as expected. However, the most crucial difference has emerged in the Gini coefficients of both groups. The data presented in Table 6 suggests that the wealth distribution among untitled individuals was better than those of titled individuals in the long term. The sample also shows that there is a significant difference in the number of observations. This probably emerges from the fact that titled individuals refrained from involving legal process. Secondly, higher average wealth levels may emerge from biases in Ottoman courts. It can be assumed that court officials might record inventories of titled individuals with higher prices than market prices (Ceylan, 2016; Canbakal \& Filiztekin, 2021). The selection bias in inheritance records of titled individuals directs us to examine the average wealth levels of untitled individuals in evaluating Ottoman economic performance in a long-term perspective. The main reason is that there should be fewer effects of data limitations on the values of untitled individuals. Gini coefficients and average wealth levels, in this sense, have reflected more accurate values for the Ottoman economy. Even if there are significant deviations in average wealth levels of the wealthiest quartile, changes in the last three quartiles are more compatible with economic performance. Thus, there is a positive relationship between the findings presented in Table 6 and other economic variables (Table 1 and 2).

\section{CONCLUSION}

Based on data collected from inheritance records, this study has examined shifts in average wealth levels and distribution of wealth in a long-term perspective. Instead of estimating absolute individual wealth levels, we have established a comparative perspective on average wealth levels by sub-periods, covering 250 years from the middle of the seventeenth century. The major findings of this study are compatible with the economic performance of the Ottoman Empire in an institutional context. Per capita GDP levels and tax revenues have generated historical evidence to examine the long-term trend of average wealth levels of individuals. The findings are also consistent with the longstanding presumption that based on better economic performance emerged in societies that achieved better wealth distribution. It is seen that the periods that contained better Gini coefficients are also periods of economic growth of the Ottoman Empire. Our findings also identify institutional factors and their roles on average wealth levels and Gini coefficients. However, this examination is based on an implicit analysis due to the lack of data on institutional change.

The major contribution of this study is to examine individual wealth with a comprehensive analysis. The perspective presented contributes to the growing literature on the individual wealth of the Ottoman Empire. Our results provide historical evidence for some of the arguments about the effects of institutional change on wealth analysis. Privatized state offices through tax-farming contracts may cause deterioration in wealth distribution within the economic structure. This must have led the central authority to impose political reforms and economic transformations on highly centralized structures. The findings provide quantitative evidence to the literature of institutional change in the Ottoman Empire. Further research on inheritance records may allow economic historians to establish well-structured data series for quantitative and econometric analyses. Thus, these findings can be tested comprehensively and discuss the major findings of this study.

\section{DECLARATION OF THE AUTHORS}

Declaration of Contribution Rate: The authors have equal contributions.

Declaration of Support and Thanksgiving: No support is taken from any institution or organisation.

Declaration of Conflict: There is no potential conflict of interest in the study. 


\section{REFERENCES}

Acemoğlu, D, \& Robinson, J. A. (2012). Why nations fail? The origins of power, prosperity and poverty. Profile Books.

Alfani, G., Di Tullio, M, \& Fochesato, M. (2020). The determinants of wealth inequality in the Republic of Venice (1400-1800) (CAGE Working Paper, no. 483). Competitive Advantage in the Global Economy (CAGE).

Altay, B, \& Bulut, M. (2017). Vakfiyeler 1şı̆̆ında Osmanlı Makedonya'sında bulunan para vakıflarının sosyoekonomik analizi, 1506-1912. Adam Academy Journal of Social Sciences, 7(2), 209-237.

Anderson, T. L. (1975). Wealth estimates for New England colonies, 1650-1709. Explorations in Economic History, 12(2), 151-176.

Arslantaş, Y. (2019). Making sense of müsadere practice, state confiscation of elite wealth, in the Ottoman Empire, circa 1453-1839. History Compass, 17(6), e12548.

Balla, E, \& Johnson, N. D. (2009). Fiscal crisis and institutional change in the Ottoman Empire and France. The Journal of Economic History, 69(3), 809-845.

Barkan, Ö. L. (1966). Edirne askeri kassamına ait tereke defterleri (1545-1659). Belgeler, 3(5-6), 1-479.

Barkan, Ö. L. (1980). Türkiye'de toprak meselesi. Gözlem.

Barkey, K. (1994). Bandits and bureaucrats: The Ottoman route to state centralization. Cornell University Press.

Bengtsson, E., Missiaia, A., Olsson, M, \& Svensson, P. (2018). Wealth inequality in Sweden, 1750-1900. Economic History Review, 71(3), 772-794.

Brandt, L., Ma, D, \& Rawski, T. G. (2014). From divergence to convergence: Reevaluating the history behind China's economic boom. Journal of Economic Literature, 52(1), 45-123.

Bulut, M, \& Altay, B. (2021). The Ottoman economy (1870-1913): Preliminary second-generation estimates. Turkish Journal of Islamic Economics, 8(2), xx-Xx.

Canbakal, H, \& Filiztekin, A. (2021). Wealth and demography in Ottoman probate inventories: A database in very long-term perspective. Historical Methods, 54(2), 94-127.

Ceylan, P. (2016). Ottoman inheritance inventories as a source for price history. Historical Methods, 49(3), 132144.

Chor, D. (2005). Institutions, wages, and inequality: The case of Europe and its periphery (1500-1899). Exploration in Economic History, 42, 547-566.

Çizakça, M. (1996). A comparative evolution of business partnerships: The Islamic world and Europe, with wpecific reference to the Ottoman archives. Brill.

Coşgel, M, \& Ergene, B. A. (2011). Intergenerational wealth accumulation and dispersion in the Ottoman Empire: Observations from eighteenth-century Kastamonu. European Review of Economic History, 15, 255-276.

Coşgel, M, \& Ergene, B. A. (2012). Inequality of wealth in the Ottoman Empire: War, weather, and long-term trends in eighteenth-century Kastamonu. The Journal of Economic History, 72(2), 308-331.

Darling, L. (1996). Revenue-rising and legitimacy: Tax collection and finance administration in the Ottoman Empire, 1560-1660. Brill.

Ergene, B. (2002). Costs of court usage in seventeenth- and eighteenth-century Ottoman Anatolia: Court fees as recorded in estate inventories. Journal of the Economic and Social History of the Orient, 45(1), 20-39.

Ergene, B, \& Berker, A. (2009). Inheritance and intergenerational wealth transmission in eighteenth-century Kastamonu: An empirical investigation. Journal of Family History, 34(1), 25-47.

Ergene, B. A., Kaygun A, \& Coşgel, M. (2013). A temporal analysis of wealth in eighteenth century Ottoman Kastamonu. Continuity and Change, 28(1), 1-26. 
Genç, M. (2000). Osmanlı Imparatorluğu'nda devlet ve ekonomi. Ötüken.

Genç, M, \& Özvar, E. (2006). Osmanlı maliyesi: Kurumlar ve bütçeler I. Osmanlı Bankası Arşiv ve Araştırma Merkezi.

Greif, A. (2006). Institutions and path to the modern economy. Cambridge University Press.

Hoffman, P. T. (2015). Why did europe conquer the world?. Princeton University Press.

Hoffman, P. T., Jacks, D., Levin, P. A, \& Lindert, P. H. (2002). Real inequality in Europe since 1500. The Journal of Economic History, 62(2), 322-355.

İnalc1k, H. (1994). An economic and social history of the Ottoman Empire, 1300-1914. Cambridge University Press.

Inalc1k, H. (2017). The Ottoman Empire and Europe: The Ottoman Empire and its place in European history. Kronik.

Jones, A. H. (1970). Wealth estimates for the American middle colonies, 1774. Economic Development and Cultural Change, 18(4), 1-172.

Karaman K, \& Pamuk, Ş. (2010). Ottoman state finances in European perspective, 1500-1914. The Journal of Economic History, 70(3), 593-629.

Karaman K, \& Pamuk. Ş. (2013). Different paths to the modern state in Europe: The interaction between warfare, economic structure, and political regime. American Political Science Review, 107(3), 603-626.

Kennedy, P. (1988). The rise and fall of the great powers. Unwin Hyman.

Kiser, E, \& Kane, J. (2001). Revolution and state structure: The bureaucratization of tax administration in early modern England and France. American Journal of Sociology, 107(1), 183-223.

Kotzageorgis, P, \& Papastamatiou, D. (2014). Wealth accumulation in an urban context. Turkish Historical Review, 5(2), 165-199.

Kuran, T. (2011). The long divergence: How Islamic law held back the Middle East. Princeton University Press.

Ma, D, \& Rubin, J. (2019). The paradox of power: Principal agent problems and administrative capacity in Imperial China (and other absolutist regimes). Journal of Comparative Economics, 47(2), 277-294.

Maddison, A. (2001). The world economy: A millennial perspective. OECD Publishing.

Maddison, A. (2003). The world economy: historical statistics, OECD Publishing.

North, D. C. (1990). Institutions, institutional change and economic performance. Cambridge University Press.

North, D. C., Wallis, J. J, \& Weingast, B. R. (2009). Violence and social orders: A conceptual framework for interpreting recorded human history. Cambridge University Press.

Özmucur, S, \& Pamuk, Ş. (2002). Real wages and standards of living in the Ottoman Empire, 1489-1914. The Journal of Economic History, 62, 292-321.

Pamuk, Ş. (2000). A monetary history of the Ottoman Empire. Cambridge University Press.

Pamuk, Ş. (2004a). Institutional change and the longevity of the Ottoman Empire, 1500-1800. The Journal of Interdisciplinary History, 35(2), 225-247.

Pamuk, Ş. (2004b). Prices in the Ottoman Empire, 1469-1914. International Journal of Middle East Studies, 36, 451-468.

Pamuk, Ş. (2009). Changes in factor markets in the Ottoman Empire, 1500-1800. Continuity and Change, 24(1), 107-136.

Pamuk, Ş. (2010). Osmanlı ekonomisi ve kurumları I. İş Bankası Kültür Yayınları. 
Root, H. (1989). Tying the king's hands: Credible commitment and royal fiscal policy during the old regime. Rationality and Society, 1(2), 240-258.

Rubin, J. (2017). Rulers, religion and riches: Why the west got rich and the Middle East did not?. Cambridge University Press.

Salzmann, A. (1993). An ancien regime revisited: "Privatization" and political economy in the eighteenth-century Ottoman Empire. Politics \& Society, 21(4), 393-423.

Salzmann, A. (2004). Tocqueville in the Ottoman Empire: Rival paths to the modern state. Brill.

Shammas, C. (1978). Constructing a wealth distribution from probate records. The Journal of Interdisciplinary History, 9(2), 297-307.

Tezcan, B. (2010). Second Ottoman Empire: Political and social transformation in the early modern world. Cambridge University Press.

Tilly, C. (1990). Coercion, capital and European states, 990-1992. Basil Blackwell.

Van Zanden, J. L. (1995). Tracing the beginning of the Kuznets curve: Western Europe during the early modern period. Economic History Review, 48(4), 643-664.

Van Zanden, J. L. (2003). Inequality of wealth of income distribution. In J. Mokyr (Ed.), Oxford Encyclopedia of Economic History (p. 56-59). Oxford University Press.

Van Zanden, J. L. (2009). The long road to the industrial revolution: The European economy in a global Perspective. Brill.

Vester, M. (2004). The political autonomy of a tax-farm: The Nice-Piedmont gabelle of the Dukes of Savoy, 15351580. The Journal of Modern History, 76(4), 745-792.

Yaycığlu, A. (2016). Partners of the empire: The crisis of the Ottoman order in the age of revolutions. Stanford University Press. 
Süleyman Demirel Üniversitesi Vizyoner Dergisi, Yıl: 2022, Cilt: 13, Sayı: 33, 236-253.

Süleyman Demirel University Visionary Journal, Year: 2022, Volume: 13, No: 33, 236-253.

Appendix 1. Court Records of Different Towns

Adana, 10 - 129; Amasya, 22 - 61; Ankara, 1 - 945; Antakya, 18; Antalya, 7 - 34; Antep, 71 - 131; Balıkesir, 692, 1229; Bodrum, 167; Bolu, 836; Bozkır, 337; Çanakkale, 163; Çankırı, 22-26; Çorum, 11; Fatsa, 72; İstanbul, 62; Kandıra, 381; Karahisar, 544 - 652; Karaman, 296; Kastamonu, 60; Kayseri, 91 - 212; Konya, 7 - 80; Kütahya, 1 - 72; Manisa, 6 - 189; Mardin, 179; Mesudiye, 1465; Milas, 149; Niğde, 11; Rize, 1495; Samsun, 1759, 1763; Seydişehir, 230; Siirt, 420; Sivas, 14 - 590; Tekirdağ, 1751; Tokat, 3-63; Vidin 10. 